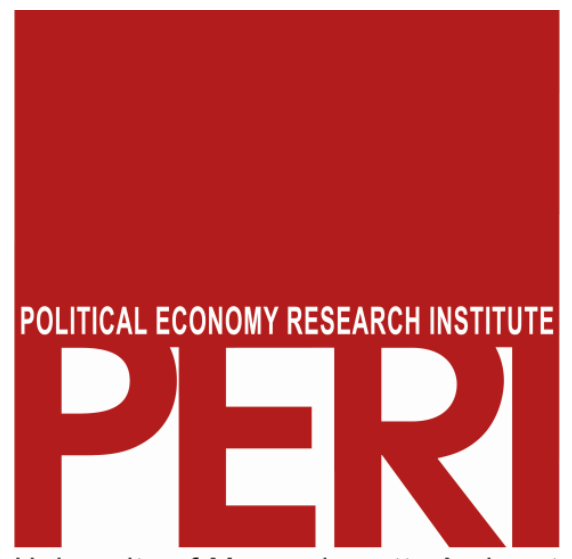

University of Massachusetts Amherst

From Internal Imbalances to Global Imbalances: A Survey on the Causes of China's Export-Led Growth

\author{
Simon Sturn
}

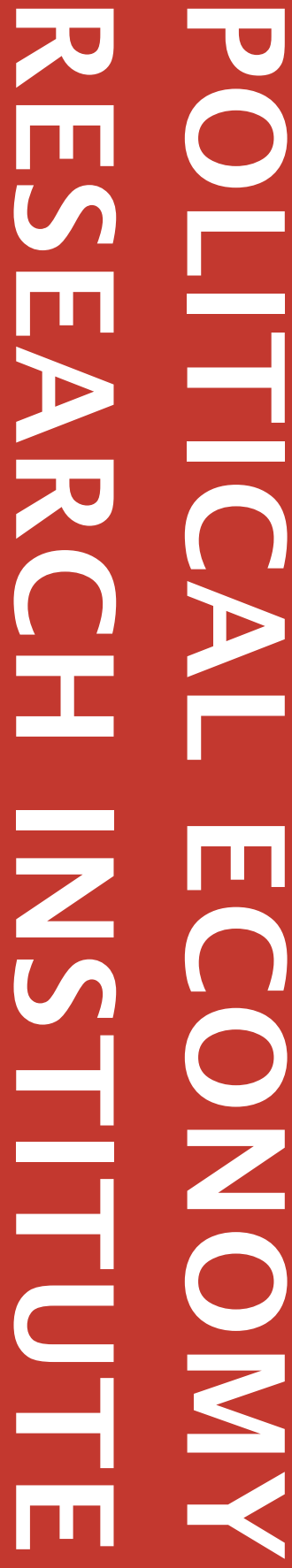

June 2014 


\title{
From internal imbalances to global imbalances: A survey on the causes of China's export-led growth
}

\author{
Simon Sturn ${ }^{\star}$ \\ First Submission: February, 2013; Revised submission: February, 2014
}

\begin{abstract}
There is a broad consensus that China's export- and investment-led growth model is unsustainable and therefore needs to become more balanced. In the public debate, Chinese exchange rate interventions are mostly made (solely) responsible for this. But it is unclear whether and how much the Renminbi is undervalued, and if an exchange rate appreciation helps to reduce China's current account surplus significantly. This survey reviews the international literature on China's export-oriented growth model. Structural internal imbalances in the Chinese economy, resulting in an extremely low consumption-to-GDP share by historical and international standards play hereby a central role. Related to this are: 1.) the drop in household and wage income as a share of GDP and low employment growth, and its impact on consumption demand; 2.) the increase in income uncertainty and inequality, and its impact on household savings; and 3.) the role of government spending, i.e. high and increasing public surpluses. The central policy challenge is therefore to increase household incomes, and to reduce income inequality and uncertainty.
\end{abstract}

\section{Keywords}

China, global imbalances, current account surplus, household income, household savings, income uncertainty, income inequality, literature survey

\section{JEL classifications}

D1, D3, E2, F00, F31

\footnotetext{
^ Simon Sturn, University of Massachusetts, 932 Thompson Hall, Amherst, MA 01003, USA. E-mail: s.sturn@econs.umass.edu. I especially thank Till van Treeck for very helpful comments and discussions. I also thank James Boyce, Hao Qi, Klara Zwickl, An Li, the participants of the ILO conference "Regulating for Decent Work: Regulating for a Fair Recovery", 6-8 July 2011, in Geneva, Switzerland, and Marcos Chamon for generously sharing his data.
} 


\section{Introduction}

There is a broad consensus among economists, international organisations and the Chinese government that China's export- and investment-led growth model is unsustainable and therefore needs to become more balanced (World Bank, 2011). The policy debate in the United States is especially concerned with the large bilateral trade deficit with China, and capital inflows from there. It has been argued, in particular, that China, along with other emerging economies, has contributed to the "global savings glut" and, by consequence, to the low long-term interest rate in the Unites States which may have fuelled the real estate bubble leading up to the Great Recession (e.g. Bernanke, 2005, 2009; Caballero et al. 2008b; Obstfeld and Rogoff, 2010; Rajan, 2010; see Palley, 2012, for a critique).

Global current-account imbalances have been at the core of the scientific and policy debate on international macroeconomics already for several years before the Great Recession. Figure 1 shows the development of current account balances as a share of world output for various countries and country groups over the last three decades. On the eve of the crises in 2007, the U.S. was by far the biggest single contributor on the deficit side, while on the surplus side it was China (closely followed by Germany ${ }^{1}$ ).

Whereas some interpreted the global imbalances as a stable equilibrium (e.g. Cooper 2007, Caballero et al. 2008a, Mendoza et al., 2009), others argued that they have the potential to threaten global macroeconomic stability (e.g. Krugman 2007, Obstfeld and Rogoff 2007). With the Great Recession the view of most economists on global imbalances significantly changed, moving toward the latter interpretation. Currentaccount imbalances are now often seen as the result of unsound fundamentals like "bubble-driven asset booms or excessively rosy expectations about future growth" (Blanchard and Milesi-Ferretti, 2009, p. 4). But also surpluses may be a result of distortions, such as high private savings because of a lack of social insurance, the accumulation of foreign assets for purposes of self-insurance against speculative attacks, or export-led growth strategies, "that is, a policy combination of a depreciated real exchange rate and enforced low domestic demand (through high saving and/or low investment)" (Blanchard and Milesi-Ferretti, 2011, p. 8).

Meanwhile, a consensus among economists and policy-makers is emerging that global imbalances are an important underlying cause of the Great Recession (e.g. Bernanke 2009, Blanchard and Milesi-Ferretti 2011, Caballero et al. 2008b, Chinn et al. 2010, various contributions in Claessens et al. 2010, Obstfeld and Rogoff 2010, Rajan 2010). To mention some prominent examples, Caballero, Farhi, and Gourinchas, who described global imbalances as an equilibrium outcome before the crisis (Caballero et al. 2008a), more

\footnotetext{
${ }^{1}$ See van Treeck and Sturn (2012, Chapter 4) on the origins of Germany's current account surplus.
} 
recently argued "that the persistent global imbalances of recent decades [and] the subprime crisis [...] are tightly interconnected" (Caballero et al., 2008b, p. 1). They interpret the global imbalances as a result of asymmetric financial development and growth prospects in different regions of the world. The Southeast Asian crisis at the end of the 1990s, the fast growth in China, and the rise in commodity prices led to a scarcity in sound and liquid financial assets. This resulted in large capital flows to the United States and to a decline in world and U.S. real interest rates, which encouraged U.S. households "to take on more housing risk than they could bear, risks that then disappeared as if by magic from the mortgage-backed securities and other structured investment vehicles whose supply exploded over the same period" (Caballero et al., 2008b, p. 3).

Obstfeld and Rogoff (2010) argue that the crisis has three main roots: first, the high and rising real estate values in some countries; second, the simultaneously high and rising current account deficits in these countries; and third, the high leverage that built up, especially among consumers in the U.S. and Britain and financial entities, combined with deregulated financial markets. They argue that "the global imbalances did not cause the leverage and housing bubbles, but they were a critically important codeterminant. [...] The United States' ability to finance macroeconomic imbalances through easy foreign borrowing allowed it to postpone tough policy choices [like tighten monetary policy] [...]. Foreign banks' appetite for assets that turned out to be toxic provided one ready source of external funding for the U.S. deficit." (Obstfeld and Rogoff 2010, p. 132-133) The reason for this appetite for U.S. assets is mainly seen as an effect of the Eastasian crisis (1997/98), which resulted in a massive accumulation of foreign currency reserves as a precaution against financial crisis in these former deficit countries, export-led growth strategies in China and other countries, and an acceleration of financial innovation in the U.S., combined with the demand for structured financial products by European banks to reduce their required regulatory capital under the Basel II framework.

Chinn, Eichengreen, and Ito (2010) argue that the global imbalances of the last decade "enabled China and other emerging markets to export their way to higher incomes. They allowed their central banks to protect themselves from capital-flow volatility by accumulating war chests of foreign reserves. They supported buoyant asset markets and rising consumption in the advanced economies despite what were, in many cases, slowly-growing or stagnant real wages.” (Chinn et al. 2010, p. 1)

In the public debate it is often argued that exchange rate manipulation in China is the primary cause of the country's massive trade imbalances with the United States (e.g. Goldstein and Lardy, 2006; Krugman, 2010, 2011). High-ranked U.S. politicians openly support special tariffs on imports from China, while U.S. President Barack Obama publicly criticised the Chinese exchange rate policy in front of China's President $\mathrm{Hu}$ Jintao. There is no consensus, however, about the extent to which the Renminbi is actually undervalued, 
with estimates ranging from close to zero (Cheung et al., 2007, 2011) to up to 20 or even 50 per cent vis-àvis the U.S. dollar (e.g. Goldstein and Lardy, 2006; Cline and Williamson, 2011; Ferguson and Schularick, 2011). Questions have also been raised about the notion that more exchange rate flexibility would significantly decrease China's current account surplus (McKinnon, 2006; Lin et al., 2010; Reisen, 2010; Benassy-Quere et al., 2011; Song et al., 2011), at least if not accompanied by structural changes in social and economic policy boosting consumption.

Although exchange rate policy is likely to play a significant role, there is more to the Chinese export-led growth model than merely an undervalued currency. Kujis and Wang (2005, p. 8), for example, conclude that "[ $t]$ he current pattern of growth and resulting consequences for resource intensity and income inequality could be linked to the growth strategy the government has pursued in the past." In line with this assessment, there is a broad consensus that structural measures need to be taken in order to increase consumption as a share of output (Kuijs and Wang, 2005; Blanchard and Giavazzi, 2006; Yu, 2007; Prasad, 2009; Guo and N'Diaye, 2009; Huang and Tao, 2010; Reisen, 2010; Song et al., 2011; Lu and Gao, 2011, Yang 2012), to reduce overcapacities in the industrial sector (Prasad, 2009; Zhu and Kotz, 2011; Blanchard and Giavazzi, 2006), and to address the problems of environmental degradation (Huang and Tao, 2010), as well as internal political tensions as a result of high income inequality especially between rural and urban areas (Kuijs and Wang, 2005), and external macroeconomic imbalances (Blanchard and Giavazzi, 2006; Yu, 2007; Prasad, 2009; Guo and N'Diaye, 2009; Huang and Tao, 2010; Razmi, 2010; Lu and Gao, 2011; Muto and Fukumoto, 2011; IMF, 2011).

In particular, there is an emerging view that China's large and rising current account surplus and weak consumption demand are linked to the rise in both functional and personal income inequality. A joint IMFILO working paper notes that "in China, lagging household income and large corporate profits have resulted in high national savings and a strong export orientation to compensate for relatively weak domestic demand" (IMF-ILO, 2010, p. 8). Justin Yifu Lin, former Chief Economist of the World Bank, notes:

"We know from the national accounts and from industry data that a large share of Chinese national income accrues to large corporations, and we also know that an increasing share of income accrues to rich people. Both groups have higher propensities to save than the middle-income and low-income households. [...] This pattern of income distribution increases investment and the accumulation of productive capacity while repressing domestic consumption, leading to a large current account surplus. Shifting more income towards workers can rebalance income between rich and poor and between the corporate sector and households.

This redistribution would also reduce external imbalances." (Lin, 2011, p. 9; see also Lin et al. 2010)

Kumhof et al. (2012) focus more on the rising personal inequality in emerging economies including China and argue that "their large surpluses can [...] be explained by increases in income inequality, [...] against the background of domestic financial markets that do not allow the poor and middle class to respond to 
lower incomes by borrowing" (Kumhof et al., 2012, p. 5). Similarly Lu and Gao identify rising income inequality as responsible for the external imbalances in China:

"The internal imbalance - reflected in the decreasing share of consumption in GDP relative to investment and export-driven growth - is basically linked to China's widening income inequality." (Lu and Gao, 2011, p. 103)

The outline of this paper is as follows: In Section 2 it will be described how income distribution might affect the composition of output and therefore the current account balance. Section 3 proceeds by discussing the evolution of functional and personal income distribution together with the composition of aggregate demand in China over past decades. Section 4 discusses the role of institutional distortions in labour and financial markets in explaining the low share of personal disposable income in national income and, by implication, China's falling consumption-to-GDP ratio. Section 5 reviews the literature that seeks to explain the rise in household savings. Further, the importance of government spending for aggregate consumption is considered in Section 6. Finally, Section 7 summarises and concludes.

\section{Approach of this study}

The current account (CA) is defined as the sum of the private sector savings-investment balance and the government budget balance (Equation 1). The former is the difference between national savings (S) and gross private domestic investment (I), the latter consists of tax receipts net of transfer payments (T) minus government spending $(\mathrm{G})$. The private sector savings-investment balance (S-I) consists of the sectorial balances of the households $\left(\mathrm{Y}^{\mathrm{HH}}-\mathrm{C}-\mathrm{I}^{\mathrm{HH}}\right)$ and corporations $\left(\mathrm{Y}^{\mathrm{F}}-\mathrm{I}^{\mathrm{F}}\right)$, where $\mathrm{Y}^{\mathrm{HH}}$ stands for household disposable income, $\mathrm{C}$ for private consumption, $\mathrm{I}^{\mathrm{HH}}$ for private household investment, $\mathrm{Y}^{\mathrm{F}}$ for business income, or cash flow, and $\mathrm{I}^{\mathrm{F}}$ for private business investment. This expression defines the current account as the savings-investment gap disaggregated for each sector of the economy - households, non-financial and financial corporations, and the government - what is called sectorial net financial investment or financial balances.

$$
C A=(S-I)+(T-G)=\left(Y^{H H}-C-I^{H H}\right)+\left(Y^{F}-I^{F}\right)+(T-G)
$$

There are two main lines along which the distribution of income is potentially important in explaining patterns of output and the current account. First, the redistribution from household income to business income might increase (decrease) the private sector savings-investment balance, depending on differences in the sectorial savings rates. Second, if the richer households save more (less) than the poorer households, an increase in income inequality will increase (decrease) the household savings-investment balance. 
To address this topic from a slightly different perspective, there seems to be a uniform consensus in the literature that an important reason for China's current account surplus has to be seen in its low and falling consumption share. Private consumption accounts for by far the largest part of GDP in most countries, but only about 35 per cent in China, and it correlates strongly and negatively with the current account. ${ }^{2}$ Equation (2) states that, again in a purely mechanical sense, a decrease (increase) in the share of private consumption in total income or output ${ }^{3}(\mathrm{Y})$ can be due to either a decrease (increase) in the share of household income in total income, or an increase (decrease) in the personal savings rate $(s)$, or both:

$$
C / Y=(1-s) Y^{H H} / Y
$$

The distribution of income between firms and private households can be seen to affect the composition of aggregate demand in a situation where the "corporate veil", separating businesses and their owners, has effective economic significance (Bhaduri and Marglin, 1990; Atkinson, 2009). For example, there may be institutional or other factors that hamper the distribution of corporate profits, especially so in a country with a large state-owned sector, or affect the cost and allocation of labour and capital through political factors (subsidies, taxes, bargaining power of workers and employers, etc.). Under these circumstances, changes in the distribution of income that are favourable to firms' retained profits at the expense of household income will result in a decrease in the consumption-to-GDP ratio. Redistribution from business income to household income will have the opposite effect.

The distribution of personal income can affect private household saving behaviour in various ways. For example, higher income dispersion may lead to higher precautionary saving, especially in the presence of credit constraints, or induce status seeking via wealth accumulation.

\section{Trends in aggregate demand and income distribution}

In the late 1970s China started a process of economic reforms and it has since impressed the world with high and sustained growth. From 1979 to 2010 the average rate of GDP growth (per capita) was as high as 9.9 (8.8) per cent, compared to 3.6 (1.2) per cent in low-income countries, and a world average of 3.0 (1.5) per cent (figures taken from the World Development Indicators). Although its per capita GDP is still relatively low, China has become the world's second largest economy since the year 2010, measured in current U.S. Dollars. This strong growth for more than three decades helped to sharply reduce absolute poverty.

\footnotetext{
${ }^{2}$ The correlation coefficient for the years 1978 to 2011 is -0.78 .

${ }^{3}$ For ease of exposition it is assumed that the GDP equals GNI in the following discussion.
} 
However, since the late 1990s China's growth relied increasingly on investment and net exports (Figure 2). Between 2000 and 2007 alone, gross national savings increased by 14 per cent of GDP, attaining a gross national savings rate of more than 50 per cent of GDP, "far surpassing the rates prevailing in Japan, South Korea, and other East Asian economies during the years of their miracle growth" (Yang et al., 2011, p. 1). Private consumption fluctuated around 50 per cent of GDP from 1978 to 1989, then fell to 41 per cent in 1994 before recovering to 47 per cent in 2000. Since then, private consumption has been in steady decline and dropped to around 34 per cent in 2011. Government consumption has also steadily fallen during the past decade, from 16 per cent of GDP in 2001 to 13 per cent in 2011. The massive decline in consumption was initially offset by rising investment, but led to rising net exports especially since 2004. Investment as a share of total output amounted to 48 per cent since 2009, one of the highest investment shares worldwide. All of the increases in investment came from the enterprise sector, while the ratio of private household investment to GDP fell slightly (OECD, 2010, p. 31). The trade surplus was close to 9 per cent of GDP in 2007, the current account surplus 10 per cent.

As can be seen in Figure 3, the decline in the private consumption-to-GDP ratio in the 2000s was accompanied by a decline in personal disposable income as a share of GDP, which is in turn mainly explained by the decline in labour income, and an increase in households' savings rate which reached the extremely high level of above 40 per cent in 2009. For the half decade or so before the Great Recession, the rise in the personal savings rate accounts for the bulk in the decline in the private consumption-to-GDP ratio (Guo and N'Diaye, 2010, p. 3). Personal saving as a share of GDP has continued to increase after 2002, despite the falling share of household income in GDP. The corporate and government sectors also contributed to the strong growth in gross savings in the years before the Great Recession (Figure 4). The development of the financial balances indicates that, in a mechanical sense, savings by the government sector and households were largely responsible for the strong increase in the current account balance (Figure 5). ${ }^{4}$

Figure 6 shows an alternative measure of the wage share for a longer time period. The largest part of the strong trend decline in the wage share since the 1980s is likely the result of a sectoral shift from agricultural employment, with a higher labour income share, to industrial employment (Bai and Qian, 2010). However, labour income also declined as a share of value added in the industry sector itself since the late 1990s. According to Bai and Qian (2010, p. 667) this is mainly a result of the restructuring of state-owned

\footnotetext{
${ }^{4}$ Note that according to national accounts data the corporate sector actually steadily decreased its net financial investment position from 2000 to 2009 (Figure 5). However, if the redistribution of income from households to corporations mainly was at the expense of low-income households with very low savings rates, and/or has an impact on saving preferences of households, and/or income out of profits ultimately goes only to rich households with high savings rates, it might still be a contributing factor to China's export-led growth model.
} 
companies and the increase in monopoly power. Qi (2011) presents a measure of the wage share for the period 1990-2007, excluding the agricultural and self-employed sectors, which play a significant role in China. According to these estimates, the wage share shows a declining trend over the whole period. ${ }^{5}$

Personal income inequality has strongly increased over the past decades. ${ }^{6}$ While China was characterised by very low inequality three decades ago, today inequality is relatively high by international standards (OECD, 2010, p. 147). The Gini coefficient is even higher than in the United States. One reason for this is the very pronounced rural-urban income gap (Figure 7). However, urban inequality has also been steadily increasing since the 1980s, and in 2007 the Gini coefficient for urban incomes in China was nearly as high as the Gini for total household income in the United States (OECD, 2010, figure 5.1, p. 130). It seems that the secular rise in inequality eased in 2006 and 2007, perhaps partly due to policy measures aiming at reducing inequality, such as tax reforms, the abolishment of school fees, and the introduction of welfare assistance programs (see OECD, 2010, ch. 5, for a discussion).

Rising urban inequality is also evident in the growth of top income shares (Figure 8). The available data show relatively low top income shares for China, e.g. compared to the United States (Piketty and Saez, 2006). Yet, since the top income shares shown in Figure 8 are calculated from survey data, they are not readily comparable with international data from income tax statistics, and "there is some presumption that top incomes are underestimated in the survey data" (Piketty and Qian, 2009, p. 55). These concerns were fueled by a widely debated study of the National Economic Research Institute of the China Reform Foundation, arguing that official income statistics do not capture "shadow income", which is predominantly acquired by top-income households. Hence, the study concludes that "China's income gap is much wider than what authorities have acknowledged". In any event, the available data show that the share of total household income going to the top 10 per cent of households has continuously increased since the 1990s.

\section{The role of institutional distortions in suppressing household incomes and promoting the savings-investment gap}

Bai et al. (2006, p. 74) argue that "despite China having one of the highest rates of investment in the world, the return to capital in China does not appear to be significantly lower than that in the rest of the world". The combination of high growth, high profitability of investment and a high and growing current account

${ }^{5}$ Note however that self-employment data are very limited, and that calculations of adjusted wage shares are therefore not very reliable.

${ }^{6}$ There is some debate about how to accurately measure income inequality in China given issues such as data reliability, rural vs. urban inequality, migration, shadow income, etc. Yet, there is a broad consensus in the literature that income inequality increased drastically in China during the last decades.

${ }^{7}$ http://english.caixin.com/2010-08-12/100169983.html 
surplus is somewhat surprising according to conventional theory: A high investment rate should either lead to a fall in profitability and higher inflation, or to high capital inflows. Therefore, the declining share of household incomes (Figure 3) together with the strong reliance of economic growth on business investment and rising net-exports (Figure 2) are linked in the literature to a number of institutional distortions affecting the allocation of capital, labour, and natural resources. For example, Prasad (2009, p. 106) argues:

"[A] substantial fraction of this investment in China has been financed by credit provided by state-owned banks at low interest rates. Indeed, cheap capital has played a big part in skewing the capital-labor ratio and holding down employment growth [...]. In addition, local governments provide subsidized land in order to encourage investment. And energy prices continue to be administered and made available to enterprises at prices below international levels. Hence, the prices of the factors of production that serve as complementary inputs to physical capital - land and energy - are also cheap."

Similarly, Yang (2012, p. 133) mentions the "suppression of wage increases, low interest payments on loans, and low land rentals to subsidize enterprises" as reasons for the Chinese saving and investment puzzle, while Dooley et al. (2005) argue the Chinese government influences wages, interest rates, and international financial transactions so as to boost export-led growth. According to Huang and Tao (2010, p. 4) various "subsidies" on capital, labour, energy, land and environment "artificially increase producer incentives, raise investment returns, and improve the international competitiveness of Chinese products. [...] In addition, they also distort the broad income distribution pattern in favor of the government and the corporate sector, but at the expense of household income. This weakens consumption and further boosts external sector surplus."

These tendencies are supported by the political reward system in China. Li and Zhou (2005) note that local officials in China play a strong pro-business role as a result of fiscal decentralisation and the specificities of the political incentives system. They present empirical evidence that the provincial leaders are rewarded and punished by the central government according to the provincial economic performance. This incentives system increases competition to attract capital at the local level and results in low tax rates, hidden subsidies in energy use, and low or negative rents on land use (Yu, 2007).

\subsection{Distortions in the labour market}

Significant changes in the labour market since the 1990s also contributed to the low growth in wage and household income. Especially since the mid-1990s, state-owned enterprises were restructured, leading to massive lay-offs. The number of employees in urban state-controlled firms fell by 14 million or 25 per cent from 1998 to 2003, while the share of employment in private urban enterprises increased significantly (OECD, 2010, p. 158ff; also see Lu and Gao, 2011). At the same time employment in agriculture declined, 
and as the hukou registration system was relaxed, there was an inflow of more than 200 million people into urban areas through official or unofficial migration (Herd et al., 2010).

Institutionally, the Chinese labour market was not prepared for this new situation:

"Many of the workers newly employed in the private sector were not given contracts, so they were not covered by social security, and their labour costs were therefore lower. Such poor labour protection is partly a consequence of fiscal decentralization and performance competition between local governments which promote short-term economic growth by attracting both domestic and foreign investment, while overlooking workers' interests." (Lu and Gao, 2011, p. 106)

OECD (2010, p. 154) argues that "[t]he labour law that was in place during this transition [...] has proved ineffective in many basic areas such as ensuring that workers are actually paid and that employers join social security." ${ }^{\prime 8}$ Long working hours are the norm in many industries, with very limited payments for overtime; nearly half of urban employees had no written labour contracts in 2005, and this number rises to nine out of ten for migrant workers in domestic private companies; although minimum wages exist (set at the regional level), they are low by international standards and not generally enforced (OECD, 2010). The problems of enforcement of labour law are made worse by the fact that there is no freedom of association for workers. All unions and many grass-root initiatives are under the control of the All-China Federation of Trade Unions which is, more or less, dominated by the Communist Party (Zhu et al., 2011; OECD, 2010). Further, migrant workers officially registered as rural workers are generally not entitled to enter the social security system (Wang 2011). Fan (2001) presents evidence that labour market returns, especially in the form of medical and retirement benefits, are heavily influenced by state-controlled institutional status. Huang and Tao (2010) conclude that the institutional deficits of the Chinese labour market weaken the bargaining power of labour and benefit particularly the export industry while restraining wage and consumption growth.

\subsection{Distortions in the financial market}

Financial distortions are another oft-mentioned explanation of low household income shares and consumption, and the savings-investment gap. A few decades ago, the role of state-owned and statecontrolled banks was mainly to deliver credit to state-owned enterprises. As economic reforms proceeded and a private sector developed, the state-owned sector has been given priority by these banks (e.g. Aziz, 2006; Aziz and Cui, 2007; Prasad, 2009; Ferri and Liu, 2010; Knight and Ding, 2010; IMF, 2011; Song et al., 2011). Bank lending rates are low, easily available for state-owned firms, and there is no obvious penalty for non-repayment of loans by state-owned enterprises. These financial sector weaknesses are likely

${ }^{8}$ In 2008 a new set of labour laws was introduced in response to these problems, but it remains to be seen to what extent this new legislation will be enforced (see Herd et al., 2010). 
to contribute to the capital-intensive growth pattern and slow employment growth (Prasad, 2009, p. 106; see also Aziz and Cui, 2007, Guo and N'Diaye, 2010). Kujis and Wang (2005, p. 3) report that in the period 1978-1993 labour productivity rose by 7.0 per cent annually, while employment grew by 2.5 per cent. By contrast, during 1993-2004, labour productivity rose by 7.8 per cent per annum on average while employment growth declined to just over 1 per cent a year. A similar point is made by Blanchard and Giavazzi (2006, p. 2), who argue that "the country's capital stock is misallocated: too much in manufacturing, too little in the domestic service industry - in particular in the provision of health services." Further, in recent years state-owned enterprises started to finance investment more through retained earnings, as they became more profitable and were not required to pay dividends to their owner, the state, until very recently. This made investment in certain industries very easy to finance, even where rates of return could be expected to be low (Prasad and Rajan, 2006; Prasad, 2009).

On the other hand, many small and medium-scale firms, often in the private sector, are credit constraint and fund investment mainly through retained profits (Aziz, 2006, p. 20). Song et al. (2011) show that because of financial frictions the reallocation of production factors from less productive, externally financed stateowned enterprises with a very high capital-output ratio to more productive but credit constraint private firms can result in less demand for bank credit and higher demand for foreign assets. A reduction of these financial frictions over time might generate capital deepening in both firm types, while going ahead with even stronger increases in aggregate savings because of low initial wealth of workers. These inefficiencies in the financial sector therefore help to explain why significant parts of China's capital are invested abroad while at the same time domestic returns are high and China attracts a huge amount of foreign direct investments (see also Caballero et al., 2008a; Mendoza et al., 2009; Mao and Yao, 2012). ${ }^{9}$ The importance of retained profits for financing investment also helps to explain already high and in recent years further increasing corporate savings (Yang et al., 2011).

A further result of these financial market distortions is that households willingly hold bank deposits despite very low interest rates because of few alternatives and the rising need to save for health, education and pensions. This further reduces household incomes, and therefore consumption (IMF, 2011). Aziz (2006, p. 30) concludes that "financial distortions may be quantitatively large and that focusing on reforming [the financial] sector may be quite important in rebalancing growth towards greater dependence on consumption."

\footnotetext{
${ }^{9}$ A further explanation for this is round-tripping, where Chinese enterprises underreport exports and overreport imports to circumvent capital controls and re-invest this capital in China to receive preferential tax rates on profits (e.g. Sicular, 1998; Prasad and Wei, 2006; Fung et al., 2011).
} 


\subsection{Additional factors}

In addition to the distortions discussed above, a host of further, and in part related, factors are likely to contribute to the unbalanced growth pattern of the Chinese economy. These include, amongst others, subsidies and the tax system favouring exports (e.g. Yu, 2007; Yang et al., 2011; Defever and Riaño, 2012), China's joining of the World Trade Organization (WTO) in 2001 (e.g. Knight and Ding, 2010; Yang 2012), exchange rate manipulation (see Section 1), and rapidly rising real estate prices in some cities fuelling construction investment (e.g. IMF, 2011; World Bank, 2011; Huang et al., 2011).

However, there is substantial evidence that, as Aziz and Cui (2007, p. 29) conclude, "improving the distribution of national income between profit and household income appears to be a quantitatively important factor" when it comes to rebalancing the Chinese economy away from its reliance on investment and net exports towards greater contributions of private consumption to overall output growth.

\section{What explains the high and rising household savings rates?}

In 2007, household savings amounted to more than 23 per cent of GDP and thus contributed the largest fraction to China's national savings rate (Figure 4; corporate savings amounted to 22 per cent in the same year). In OECD countries, the bulk of national savings is attributable to business savings, although the private household sector appropriates a much larger share of national income in OECD countries than in China. Hence, the high and rapidly rising personal savings rate plays a very important role in explaining the weak development of private consumption as a share of GDP in China, especially during the 2000s. Kraay (2000) reports that household savings were only about 7 per cent of GDP in the late 1970s, making cultural norms appear as an unlikely explanation of the currently high savings rate. Below, some of the more recent attempts to explain the high and rising personal savings rate in China are summarised.

\subsection{Life-cycle and demographic effects}

On the basis of the permanent income hypothesis, it is hard to explain why Chinese households continued to save more in an environment of steadily and strongly growing household incomes, instead of smoothening lifetime consumption (e.g. Chamon and Prasad, 2010). Modigliani and Cao (2004), estimating single equations for the period 1950s to 2000, interpret their results as evidence in favour of the life-cycle hypothesis, while others conclude that the life-cycle hypothesis does not account for household savings (e.g. Chao et al., 2011). Chamon and Prasad (2010), in the first study using household data for a longer timespan (1990-2005), show that the age-savings profiles of households gradually turned into a U-shaped 
pattern, whereby young and old households have the highest savings rates (Figure 9). ${ }^{10}$ This is inconsistent with the hump-shaped profile implied by the life-cycle hypothesis, whereby young workers are assumed to save very little and savings rates peak around age 40, when potential earnings are highest.

Another oft-mentioned potential contributing factor is demographic changes due to the one-child policy. Wei and Zhang (2011) suggest that the rising sex ratio imbalance made it progressively more difficult for men to get married. Therefore, families with sons increase savings in order to improve their relative attractiveness for marriage. They show that the local sex ratio is a significant predictor for savings in households and regions. By contrast, Chamon and Prasad (2010) do not find demographic shifts and the one-child policy to provide a convincing explanation as the cohorts most affected by the one-child policy are not among the highest savers. Hence, they conclude that "the rising savings rates must be the result of economy-wide changes affecting all households." (Chamon and Prasad, 2010, p. 95)

\subsection{Income uncertainty and precautionary saving}

Another potential explanation invokes the presence of habit persistence in a context of fast income growth, which can entail some uncertainty about future consumption opportunities. Using aggregate provincial level data for 1995-2004, Horioka and Wan (2007) find strong evidence of habit persistence. Again, however, Chamon and Prasad (2010) find little empirical support for this factor when applying household data.

Following Chamon and Prasad (2010), most promising in explaining high and rising household saving in recent years are the rapid privatisation of the housing stock (combined with very limited availability of household credit), and the rising private burden of education and health expenditures, together with precautionary motives stemming from the reforms of state-owned enterprises and market-oriented reforms more generally (see Section 4). ${ }^{11}$ These issues are further pursued by Chamon et al. (2010) who use household data for the period 1989-2006 to explain household savings rates of workers. They show that income uncertainty increased strongly since the 1990s: The transition rate from employment to unemployment and from state-owned companies to non-state-owned companies increased sharply. Further, a pension reform in 1997 reduced the pension replacement rate, leading to higher savings by households approaching retirement. They proceed by arguing that "greater uncertainty in earnings at the microeconomic level can have macroeconomic implications. One important channel is the impact of greater

\footnotetext{
${ }^{10}$ The data set used by Chamon and Prasad (2010) only covers urban households, who account for about two thirds of total household income.

${ }^{11}$ They report that " $[\mathrm{t}]$ he proportion of households that own or partially own their homes increased dramatically from 17 per cent in 1990 to 86 per cent in 2005 [...], largely as a result of the housing reforms that took place over the last decade" (Chamon and Prasad, 2010, p. 114). Further, "[t]he fraction of households in our sample for which health expenditures exceed 20 per cent of total consumption expenditures (a reasonable threshold for measuring the risk of large private health expenditures) has risen from 1 per cent in 1995 to 7 per cent in 2005" (Chamon and Prasad, 2010, p. 113).
} 
household-specific uncertainty on precautionary savings. In the absence of a strong social safety net and an underdeveloped financial system, this could lead households to self-insure by increasing their savings" (Chamon et al., 2010, p. 13). ${ }^{12}$

Chamon et al. (2010) regress household income on several household characteristics, and use the residuals to estimate the permanent and transitory components of income. They then calibrate a precautionary savings model to quantify the effect of rising income uncertainty. They find that their simulation results are well able to explain the increase of the household savings rate over time, as well as the U-shaped agesavings profile of savings. According to their results, for younger households, the rise in the savings rate is explained by saving for precautionary purposes due to rising income uncertainty and for housing purchases. For older households, meanwhile, pension reforms and rising medical expenditures account for much of the rise in the savings rate.

\subsection{Rising income inequality and status-seeking through wealth accumulation}

While the finding by Chamon et al. (2010) of higher precautionary saving is consistent with others (e.g. Kraay, 2000; Kuijs, 2006; Qi and Prime, 2009), doubts remain as to whether the strong rise in income inequality, reported in Section 3, merely reflects higher income uncertainty. Chamon et al. (2010, p. 11) report that none of their income measures show evidence of a clear trend in the variance of permanent shocks, while they find a clear upward trend in the variance of transitory shocks. But Gong et al. (2010) provide evidence that intergenerational mobility in China is very low by international standards. It is wellknown that countries with a more unequal distribution of income at a given point in time typically also exhibit lower income mobility across generations (OECD, 2008, ch. 8). One reason for this is the selfreinforcing positive relationship between inequality and the private returns on education. On the one hand, education gives access to relatively well-paid jobs and, on the other hand, the ability to take advantage of the high returns on education will typically be limited to children of richer households (Carneiro and Heckman, 2002; OECD, 2008, p. 214). Moreover, it is a rather difficult task to empirically distinguish changes in transitory and permanent income inequality. This is all the more true in the Chinese context of strongly rising inequality, high intergenerational immobility and rapid overall income growth. Due to its relation with educational success, an initial increase in transitory earnings dispersion can quickly turn into higher individual lifetime inequality and further reduced intergenerational mobility.

\footnotetext{
${ }^{12}$ Chamon and Prasad (2010, p. 113) report that "[t]otal consumer loans issued by all financial institutions in China increased from near zero in 1997 to about 2.2 trillion yuan by the end of 2005 (12 per cent of GDP). Real estate loans account for about 80 per cent of total consumer loans outstanding and auto loans account for about 7.5 per cent of total consumer loans outstanding. Household consumption (from the national accounts) amounted to 7 trillion yuan in 2005."
} 
Jin et al. (2011), using household data for 1997 to 2006, present direct econometric evidence that rising inequality has positively affected household savings even when controlling for other potential explanatory factors discussed above. Their estimations explain consumption (net of education expenditures) and the average propensity to consume (ratio of consumption to disposable income) with household income, a set of control variables (such as age, family size, province and year dummies, time trends, house prices, the estimated returns on education) and a measure for income inequality. ${ }^{13}$ Overall they find a strong, robust and statistically significant negative impact of a rise in the Gini on consumption.

They also control for the increase of income risk (proxied by the proportion of families in a province-age group that experienced a decrease in income for families that are in the sample two years in a row). However, the inclusion of this variable does not show the expected sign and the coefficient of the Gini is even higher for this specification. Jin et al. (2001) further include two measures for the quality of the provincial social security net. These variables are both statistically significant and stimulate consumption, but do not affect the coefficient and significance of the Gini variable. They further experiment with the variable for the sex-ratio as used by Wei and Zhang (2011), but do not find a significant effect on either consumption or the coefficient of the Gini variable.

Jin et al. (2011) present a theoretical framework of status-seeking through the accumulation of wealth and derive further testable hypotheses and supportive empirical evidence from it. For example, inequality has stronger negative effects on the expenditures of younger consumers, as they will benefit longer from a higher status. Inequality has a positive effect on education expenditures, as education is an indicator of social status and is correlated with higher income and wealth. Finally, income inequality has no negative effect on the consumption of basic food. In line with the relative income hypothesis (Duesenberry, 1949), they attribute these results to status-seeking motives. Due to the limited access of private households to credit, social status depends to a large extent on the family's position in the wealth distribution:

"As a result, in order to ascend in the status hierarchy or keep the social status in the 'Rat Race', families try to accumulate wealth by increasing savings. When income inequality increases, the benefit gap between the high-status and low-status groups widens, which in turn strengthens the incentives of status-seeking savings. [...] Furthermore, rising income inequality also raises the entry wealth level for the high-status group, which means that more savings are needed for one to enter the high-status group." (Jin et al., 2011, p. 192).

Further evidence for the increasing impact of income inequality on household saving is presented in Figure 10. It shows savings rates of households ranked by income deciles in 1995, 2000 and 2005 from Chamon and Prasad (2010, p. 99, figure 2). Interestingly, households with high incomes not only save much more as

\footnotetext{
${ }^{13}$ Their preferred measure is the Gini coefficient within the reference province and age group, but their results do not depend on the inequality measure
} 
a percentage of their income, their savings rate has also increased over time. Chamon and Prasad (2010, p. 99) report that the top two deciles alone accounted for over half of total savings in 2005 , and that these results do not change if households are sorted by an estimated measure of permanent income. In line with these findings, Baldacci et al. (2010) present estimates that average propensities to consume out of lifetime income are much higher for low income households.

\section{A key role for government spending}

As can be seen in Figure 2, government consumption decreased as a share of GDP during the 2000s, while the government's contribution to gross savings strongly increased (Figure 4). The government's financial balance improved significantly in the years before the crisis (Figure 5), which was mainly the result of the fiscal reform of 1994, a rapidly rising tax base due to high nominal and real growth, and very low public spending, especially on social transfers (Yang, 2012). While the general government sector had a financial surplus of more than 3 per cent of GDP in 2007, China's public finance position deteriorated slightly in 2008 and 2009. However, the OECD (2010, p. 37) estimates that China "can readily accommodate a permanently higher level of government spending."

There seems to be a broad consensus in the literature that rising government spending, especially with respect to health, education and pensions, could play a key role in increasing consumption in China (e.g. Blanchard and Giavazzi, 2006; Qi and Prime, 2009; Baldacci et al., 2010; Barnett and Brooks, 2010; OECD, 2010). Higher government consumption is found to have a positive impact on consumption via three channels: First, through its direct effect; second, through its mediating effect on households precautionary saving (Qi and Prime, 2009; Barnett and Brooks, 2010); and third, through income redistribution to low income households, due to their higher propensity to consume (Baldacci et al., 2010; Yang et al., 2011; Yang 2012).

Qi and Prime (2009) use panel data across provinces for the period 1979 to 2004 to explain household consumption as a share of GDP. Private consumption is according to their estimates positively influenced by government spending on health and by financial development, and negatively by proxies for income uncertainty such as the size of the state sector or the variance of income across time for each province. While rejecting the life-cycle model, their "most significant and robust discovery is that [...] higher government spending on education and health has the biggest impact on increasing household consumption" (Qi and Prime, 2009, p. 399). This result is in part confirmed by Barnett and Brooks (2010), using pooled provincial data from 1994 to 2007. They find a large impact of government spending on health, but not education, on household consumption in urban but not rural areas. According to Barnett and 
Brooks (2010, p. 11), "each additional yuan in government health spending boosts urban consumption by 2 yuan" due to the reduction of precautionary saving.

Baldacci et al. (2010), on the basis of a panel of 24 OECD countries for the period 1990-2008, estimate the impact of government social expenditures on household savings, controlling for standard explanatory variables. They find that "a 1 per cent of GDP increase in total social spending is likely to reduce household saving by $0.14-0.24$ per cent of GDP" (p. 9). These estimation results were matched with estimated propensities to consume (out of lifetime income) for different household groups in China (urban or rural residence, age, income quintile), to simulate the impact of an increase in government expenditures on health, education and pensions. Their simulations suggest that the impact of government social spending is higher in rural than in urban areas, and that spending on pensions and health has the biggest effect on consumption: An increase in pension or health expenditure by one percentage point of GDP increases consumption by 1.6 or 1.3 per cent of GDP respectively. If these additional government expenditures were financed through higher income taxes, the net effect on consumption would be partly offset, but would still be clearly positive ( 1.0 per cent for pensions and 0.7 per cent for health).

\section{Conclusions}

In China, the share of consumption as a percentage of GDP dropped strongly since 1990, and especially since 2000, from already low levels by international comparison. Aggregate savings soared after 2000, which was only partly offset by higher investment. These factors resulted in a widening current account surplus. According to the literature reviewed, the primary reasons for these developments are:

1. Low and decreasing household income in relation to total income, especially wage income, due to distortions in the financial and labour markets, resulting in low consumption growth. Financial distortions also help to explain the increasing demand for foreign assets.

2. High and rising household savings rates due to high income uncertainty in a period of economic transition, a weak social safety net, and high and rising income inequality. The latter has increased the incentives for status seeking via wealth accumulation against the background of limited access of households to credit.

\section{Low and decreasing government consumption.}

From this analysis follows that rising income inequality and uncertainty, slow wage growth (except for top wages), and the low and declining public expenditures on health, education and pension were important factors behind the unbalanced growth pattern in China, thereby contributing to the global imbalances. In 
particular, and consistent with the relative income hypothesis (Duesenberry, 1949), and in line with the theoretical model in Kumhof et al. (2012), status-seeking in the context of rising inequality, underdeveloped credit markets, and the retrenchment of the state from the provision of health, education and pensions, led to oversaving, contributing to the rising current account surplus in China. This analysis is in stark contrast to the policy debate in the U.S., where China's current account surplus is often regarded as being solely the result of exchange rate interventions.

Van Treeck (forthcoming) reviews evidence that shows how rising income inequality, in the context of low income mobility but highly deregulated credit markets and targeted credit promotion through the government, fueled the private consumption boom and the falling personal savings rate in the United States. In China, by contrast, access to personal credit is very limited. Households cannot easily use credit to compete in the "rat race" and must therefore rely on savings. In that sense, rising income inequality in combination with other institutional factors contributed to both, current account deficits in the United States, and current account surpluses in China (see also Kumhof et al., 2012).

A reduction of financial distortions and the broader availability of household and firm credit in China might be seen as an obvious policy conclusion to reduce the adverse impact of inequality on saving and to boost domestic demand. But as noted by Kumhof et al. (2012, p. 5) this could easily lead to overindebted households if not accompanied by a reduction in income inequality:

"A short-sighted response to global imbalances might therefore be to reduce these 'financial market imperfections' in surplus countries. However, if this policy is administered without addressing the underlying income inequalities, it will result in a global rather than a regional increase in domestic indebtedness of the poor and middle class. While this would reduce cross-border financial fragilities, it would exacerbate domestic financial fragilities. In the long run there is therefore no alternative to directly addressing the income inequality problem."

Therefore the central policy challenge is not simply to appreciate the Renminbi or develop financial markets, but also to increase household incomes, reduce income inequality and uncertainty, and to create a macroeconomic environment where the broader availability of credit does not lead to the emergence of credit bubbles. 


\section{References}

Atkinson, A. (2009), Factor shares: The principal problem of political economy?, Oxford Review of Economic Policy 25(1), 3-16.

Aziz, J. (2006), Rebalancing Chinas Economy: What Does Growth Theory Tell Us?, IMF Working Papers (06/291), International Monetary Fund.

Aziz, J. \& Cui, L. (2007), Explaining Chinas Low Consumption: The Neglected Role of Household Income, IMF Working Papers (07/181), International Monetary Fund.

Bai, C.-E.; Hsieh, C.-T. \& Qian, Y. (2006), The return to capital in China, Brookings Papers on Economic Activity 37(2), 61-102.

Bai, C.-E. \& Qian, Z. (2010), The factor income distribution in China: 1978-2007, China Economic Review 21(4), 650-670.

Baldacci, E.; Callegari, G.; Coady, D.; Ding, D.; Kumar, M. S., Tommasino, P. \& Woo, J.; (2010), Public Expenditures on Social Programs and Household Consumption in China, IMF Working Papers (10/69), International Monetary Fund.

Barnett, S. \& Brooks, R. (2010), China: Does Government Health and Education Spending Boost Consumption?, IMF Working Papers (10/16), International Monetary Fund.

Benassy-Quere, A.; Carton, B. \& Gauvin, L. (2011), Rebalancing Growth in China: An International Perspective, Working Papers (2011-08), CEPII research center.

Bernanke, B. S. (2005), The Global Saving Glut and the U.S. Current Account Deficit, Remarks at the Sandridge Lecture, Virginia Association of Economists, Richmond, Virginia.

Bernanke, B. S. (2009), Financial Reform to Address Systemic Risk, Speech at the Council on Foreign Relations, Washington, DC, March 10.

Bhaduri, A. \& Marglin, S. (1990), Unemployment and the real wage: The economic basis for contesting political ideologies, Cambridge Journal of Economics 14(4), 375-93.

Blanchard, O. \& Giavazzi, F. (2006), Rebalancing growth in China: A three-handed approach, China \& World Economy 14(4), 1-20.

Blanchard, O. \& Milesi-Ferretti, G. M. (2009), Global Imbalances: In Midstream?, IMF Staff Position Note 09(29).

Blanchard, O. \& Milesi-Ferretti, G. M. (2011), (Why) Should Current Account Balances Be Reduced?, IMF Staff Position Note 11(03).

Caballero, R. J., Farhi, E., \& Gourinchas, P.-O. (2008a), An Equilibrium Model of "Global Imbalances" and Low Interest Rates. American Economic Review, 98(1), 358-93.

Caballero, R. J.; Farhi, E. \& Gourinchas, P.-O. (2008b), Financial crash, commodity prices, and global imbalances, Brookings Papers on Economic Activity 39(2), 1-55. 
Carneiro, P. \& Heckman, J.J. (2002), The Evidence on Credit Constraint in Post-Secondary Schooling, Economic Journal 112(482), 705-734.

Chamon, M. D. \& Prasad, E. S. (2010), Why are saving rates of urban households in China rising?, American Economic Journal: Macroeconomics 2(1), 93-130.

Chamon, M.; Liu, K. \& Prasad, E. S. (2010), Income Uncertainty and Household Savings in China, NBER Working Papers (16565), National Bureau of Economic Research.

Chao, C.-C.; Laffargue, J.-P. \& Yu, E. (2011), The Chinese saving puzzle and the life-cycle hypothesis: A revaluation, China Economic Review 22(1), 108-120.

Cheung, Y.; Chinn, M. \& Fujii, E. (2007), The overvaluation of Renminbi undervaluation, Journal of International Money and Finance 26(5), 762-785.

Cheung, Y.; Chinn, M. \& Fujii, E. (2011), A Note on the Debate over Renminbi Undervaluation, http://www.ssc.wisc.edu/ mchinn/cheung_chinn_fujii_2011.pdf.

Chinn, M.; Eichengreen, B. \& Ito, H. (2010), Rebalancing Global Growth, http://www.ssc.wisc.edu/ mchinn/Rebalancing_Global_Growth.pdf.

Claessens, S.; Evenett, S. \& Hoekman, B., eds., (2010), Rebalancing the Global Economy: A Primer for Policymaking, London: Centre for Economic Policy Research.

Cline, W. R. \& Williamson, J. (2011), Estimates Of Fundamental Equilibrium Exchange Rates, May 2011, Policy Briefs (PB11-5), Peterson Institute for International Economics.

Cooper, R. N. (2007), Living with Global Imbalances. Brookings Papers on Economic Activity 38(2), 91110.

Defever, F. \& Riaño, A. (2012), China's Pure Exporter Subsidies, CEP Discussion Paper (1182), London School of Economics and Political Science.

Dooley, M.; Folkerts-Landau, D. \& Garber, P. (2005), Direct investment, rising real wages and the absorption of excess labor in the periphery, Proceedings, Federal Reserve Bank of San Francisco (Feb).

Duesenberry, J. S. (1949). Income, Saving and the Theory of Consumer Behavior. Cambridge, MA: Harvard University Press.

Fan, C. C. (2001), Migration and labor-market returns in urban China: Results from a recent survey in Guangzhou, Environment and Planning A 33(3), 479-508.

Ferguson, N. \& Schularick, M. (2011), The end of Chimerica, International Finance 14(1), 1-26.

Ferri, G. \& Liu, L.-G. (2010), Honor thy creditors beforan thy shareholders: Are the profits of Chinese state-owned enterprises real?, Asian Economic Papers 9(3), 50-71.

Fung, H.-G., Yau, J., \& Zhang, G. (2010). Reported trade figure discrepancy, regulatory arbitrage, and round-tripping: Evidence from the China-Hong Kong trade data. Journal of International Business Studies, 42(1), 152-176.

Goldstein, M. \& Lardy, N. (2006), Chinas exchange rate policy dilemma, American Economic Review 
96(2), 422-426.

Gong, C. H.; Leigh, A. \& Meng, X. (2010), Intergenerational Income Mobility in Urban China, IZA Discussion Papers (4811), Institute for the Study of Labor (IZA).

Guo, K. \& N'Diaye, P. M. P. (2009), Is Chinas Export-oriented Growth Sustainable?, IMF Working Papers (09/172), International Monetary Fund.

Guo, K. \& N'Diaye, P. M. P. (2010), Determinants of Chinas Private Consumption: An International Perspective, IMF Working Papers (10/93), International Monetary Fund.

Herd, R.; Koen, V. \& Reutersward, A. (2010), Chinas Labour Market in Transition: Job Creation, Migration and Regulation, OECD Economics Department Working Papers (749), OECD.

Horioka, C. Y. \& Wan, J. (2007), The determinants of household saving in China: A dynamic panel analysis of provincial data, Journal of Money, Credit and Banking 39(8), 2077-2096.

Huang, Y. \& Tao, K. (2010), Factor market distortion and the current account surplus in China, Asian Economic Papers 9(3), 1-36.

Huang, Y.; Chang, J. \& Yang, L. (2011), China: Beyond the Miracle - Part 3: Bubble Deflation, Chinese Style, Barclays Capital Economic Research.

IMF (2011), Peoples Republic of China: Financial System Stability Assessment, IMF Country Report (No. $11 / 321)$.

IMF \& ILO (2010), The Challenges of Growth, Employment and Social Cohesion, Discussion Document, International Labour Organization and International Monetary Fund, Proceeding from the joint ILOIMF conference held in Oslo, Norway, on September 13th 2010.

Jin, Y.; Li, H. \& Wu, B. (2011), Income inequality, consumption, and social-status seeking, Journal of Comparative Economics 39(2), 191-204.

Knight, J. \& Ding, S. (2010), Why does China invest so much?, Asian Economic Papers 9(3), 87-117.

Kraay, A. (2000), Household saving in China, World Bank Economic Review 14(3), 545-570.

Krugman, P. (2007), Will there be a dollar crisis?, Economic Policy 22(51): 435-467.

Krugman, P. (2010), Taking on China, New York Times 2010/03/15, A23, http://www.nytimes.com/2010/03/15/opinion/15krugman.html.

Krugman, P. (2011), Holding China to Account, New York Times 2011/10/03, A25, http://www.nytimes.com/2011/10/03/opinion/holding-china-toaccount.html?_r=1\&scp=3\&sq=krugman\%20china\&st $=$ cse

Kuijs, L. (2006), How Will Chinas Saving-investment Balance Evolve?, Policy Research Working Paper Series (3958), The World Bank.

Kuijs, L. \& Wang, T. (2005), Chinas Pattern Of Growth: Moving To Sustainability and Reducing Inequality, Policy Research Working Paper Series (3767), The World Bank.

Kumhof, M.; Lebarz, C.; Ranciere, R.; Richter, A. W. \& Throckmorton, N. A. (2012), Income Inequality 
and Current Account Imbalances, IMF Working Papers (12/08), International Monetary Fund.

Li, H. \& Zhou, L.-A. (2005), Political turnover and economic performance: The incentive role of personnel control in China, Journal of Public Economics 89(9-10), 1743-1762.

Lin, J. Y. (2011), China and the Global Economy, Remarks at the Conference "Asia's Role in the PostCrisis Global Economy", San Francisco Federal Reserve Bank, November 29.

Lin, J. Y.; Dinh, H. T. \& Im, F. (2010), US-China external imbalance and the global financial crisis, China Economic Journal 3(1), 1-24.

Lu, M. \& Gao, H. (2011), Labour market transition, income inequality and economic growth in China, International Labour Review 150(1-2), 101-126.

Mao, R. \& Yao, Y. (2012), Manufacturing-Finance Comparative Advantage and Global Imbalances, Working Paper (E2012004), China Center for Economic Research, National School of Development, Peking University.

McKinnon, R. (2006), Chinas exchange rate trap: Japan redux?, American Economic Review 96(2), 427431.

Mendoza, E. G., V. Quadrini, \& J. Rios-Rull (2009). Financial integration, financial development, and global imbalances. Journal of Political Economy, 117(3), 371-416.

Modigliani, F. \& Cao, S. L. (2004), The Chinese saving puzzle and the life-cycle hypothesis, Journal of Economic Literature 42(1), 145-170.

Muto, I. \& Fukumoto, T. (2011), Rebalancing Chinas Economic Growth: Some Insights from Japans Experience, MPRA Paper (32570), University Library of Munich, Germany.

Obstfeld, M. \& Rogoff, K. (2007), The Unsustainable U.S. Current Account Position Revisited, G7 Current Account Imbalances: Sustainability and Adjustment, National Bureau of Economic Research, 339376

Obstfeld, M. \& Rogoff, K. (2010), Global imbalances and the financial crisis: Products of common causes, Asia Economic Policy Conference Volume, Federal Reserve Bank of San Francisco, 131-172.

OECD (2008), Growing Unequal?: Income Distribution and Poverty in OECD Countries, OECD.

OECD (2010), Economic Surveys of China, OECD.

Palley, T. I. (2012), From Financial Crisis to Stagnation: The Destruction of Shared Prosperity and the Role of Economics, Cambridge University Press.

Piketty, T. \& Qian, N. (2009), Income inequality and progressive income taxation in China and India, 19862015, American Economic Journal: Applied Economics 1(2), 53-63.

Piketty, T. \& Saez, E. (2006), The Evolution of top incomes: A historical and international perspective, American Economic Review 96(2), 200-205.

Prasad, E. S. (2009), Is the Chinese growth miracle built to last?, China Economic Review 20(1), 103-123.

Prasad, E. S. \& Rajan, R. G. (2006), Modernizing Chinas growth paradigm, American Economic Review 
96(2), 331-336.

Prasad, E. S. \& Wei, S.-J. (2006), Understanding the Structure of Cross-border Capital Flows: The Case of China, paper presented at the Columbia University Conference, China at Crossroads: FX and Capital Markets Policies for the Coming Decade.

Qi, H. (2011), Modernize Chinas Labor Share?, Paper presented at the ICAPE conference in Amherst, Massachusetts.

Qi, L. \& Prime, P. B. (2009), Market reforms and consumption puzzles in China, China Economic Review 20(3), 388-401.

Rajan, R. (2010), Fault Lines: How Hidden Fractures Still Threaten the World Economy, Princeton University Press.

Razmi, A. (2010), Exploring the sustainability of the Chinese growth model in light of some key structural characteristics, International Journal of Political Economy 39(1), 54-92.

Reisen, H. (2010), Is Chinas Currency Undervalued?, http://www.voxeu.org/index.php?q=node/4845.

Sicular, T. (1998), Capital Flight and Foreign Investment: Two Tales from China and Russia, The World Economy 21(5), 589-602.

Song, Z.; Storesletten, K. \& Zilibotti, F. (2011), Growing like China, American Economic Review 101(1), 196-233.

Van Treeck, T. (forthcoming), Did inequality cause the U.S. financial crisis?, Journal of Economic Surveys.

Van Treeck, T., \& Sturn, S. (2012). Income inequality as a cause of the Great Recession? A survey of current debates, Conditions of Work and Employment Series (39), International Labour Organization.

Wang, Z. (2011), Social security for Chinas migrant workers, International Labour Review 150(1-2), 177 178.

Wei, S.-J. \& Zhang, X. (2011), The competitive saving motive: Evidence from rising sex ratios and savings rates in China, Journal of Political Economy 119(3), 511-564.

World Bank (2011), China Quarterly Update, April.

Yang, D. T. (2012), Aggregate Savings and External Imbalances in China, Journal of Economic Perspectives 26(4), 125-146.

Yang, D. T.; Zhang, J. \& Zhou, S. (2011), Why are Saving Rates so High in China?, NBER Working Papers (16771), National Bureau of Economic Research.

Yu, Y. (2007), Global imbalances and China, Australian Economic Review 40(1), 3-23.

Zhou, M.; Xiao, W.; Yao, X. (2010), Unbalanced Economic Growth and Uneven National Income Distribution: Evidence from China, IRLE Working paper 2010(11), Institute for Research on Labor and Employment UC Los Angeles

Zhu, A. \& Kotz, D. M. (2011), The dependence of Chinas economic growth on exports and investment, 
Review of Radical Political Economics 43(1), 9-32.

Zhu, Y.; Warner, M. \& Feng, T., 2011, Employment relations "with Chinese characteristics": The role of trade unions in China, International Labour Review 150(1-2), 127-143. 


\section{Figures and Tables}

Figure 1: Current account balances, in per cent of world GDP, selected countries, 19802010

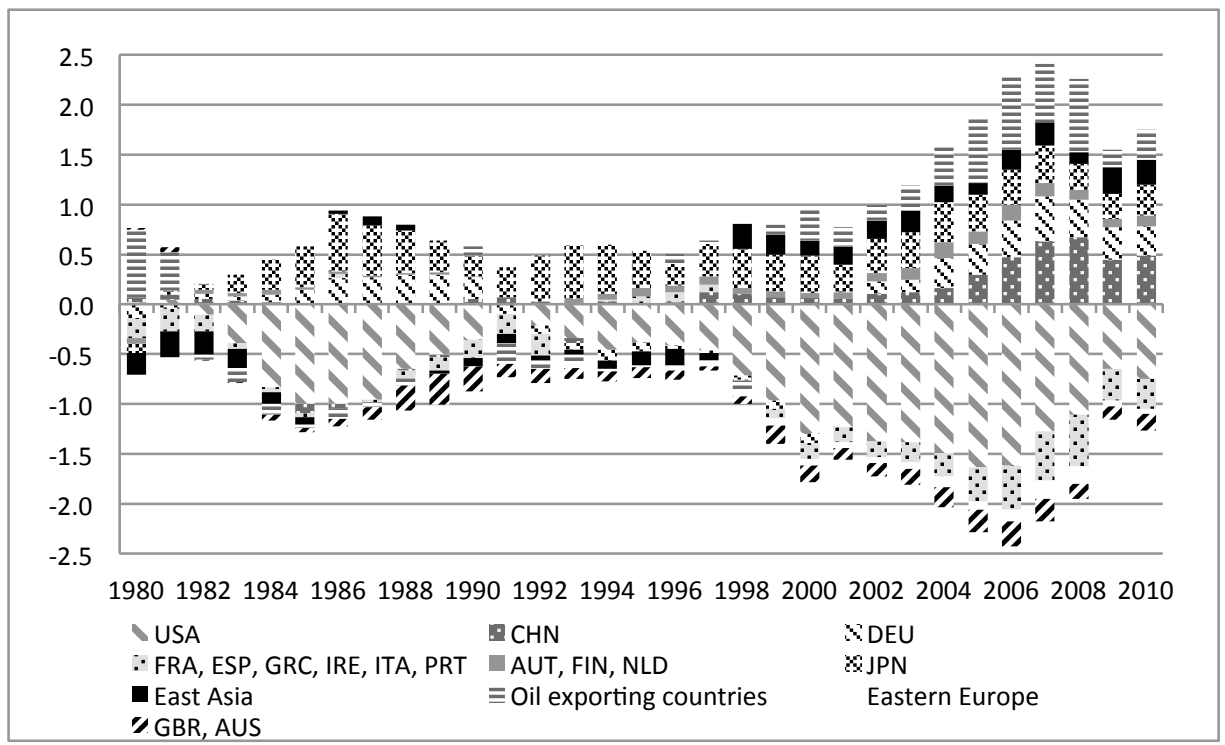

Note: Eastern Europe (since 1993): Poland, Czech Republic, Slovak Republic, Slovenia, Hungary, Bulgaria, Latvia, Lithuania, Estonia and Romania; Oil exporting countries: Arab countries, Russia (since 1994), Nigeria and Venezuela; East Asia: East Asian and Pacific countries excluding China and Japan Source: World Bank - Global Development Finance; authors' calculations

Figure 2: Household consumption, government consumption, investment, and net exports, in per cent of GDP, 1978-2011

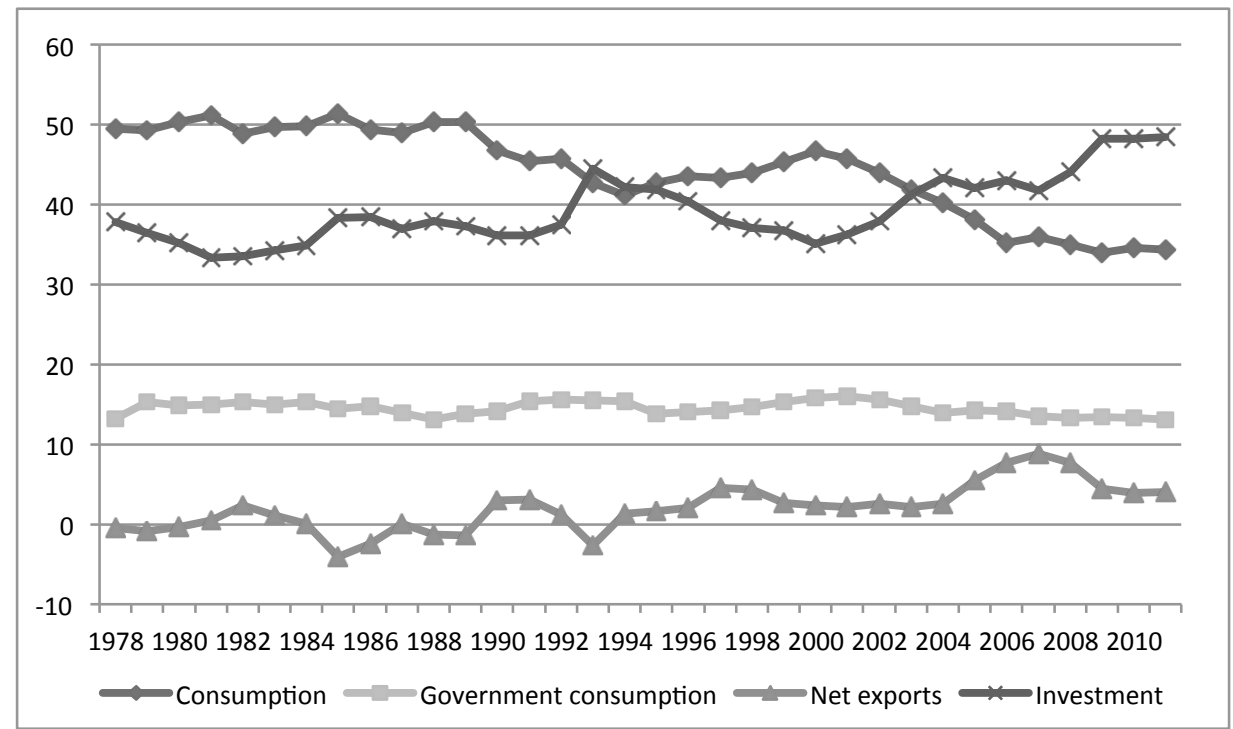

Source: World Development Indicators 
Figure 3: Compensation of employees and personal disposable income, in per cent of GDP, and household savings, in per cent of personal disposable income, 2000-2009

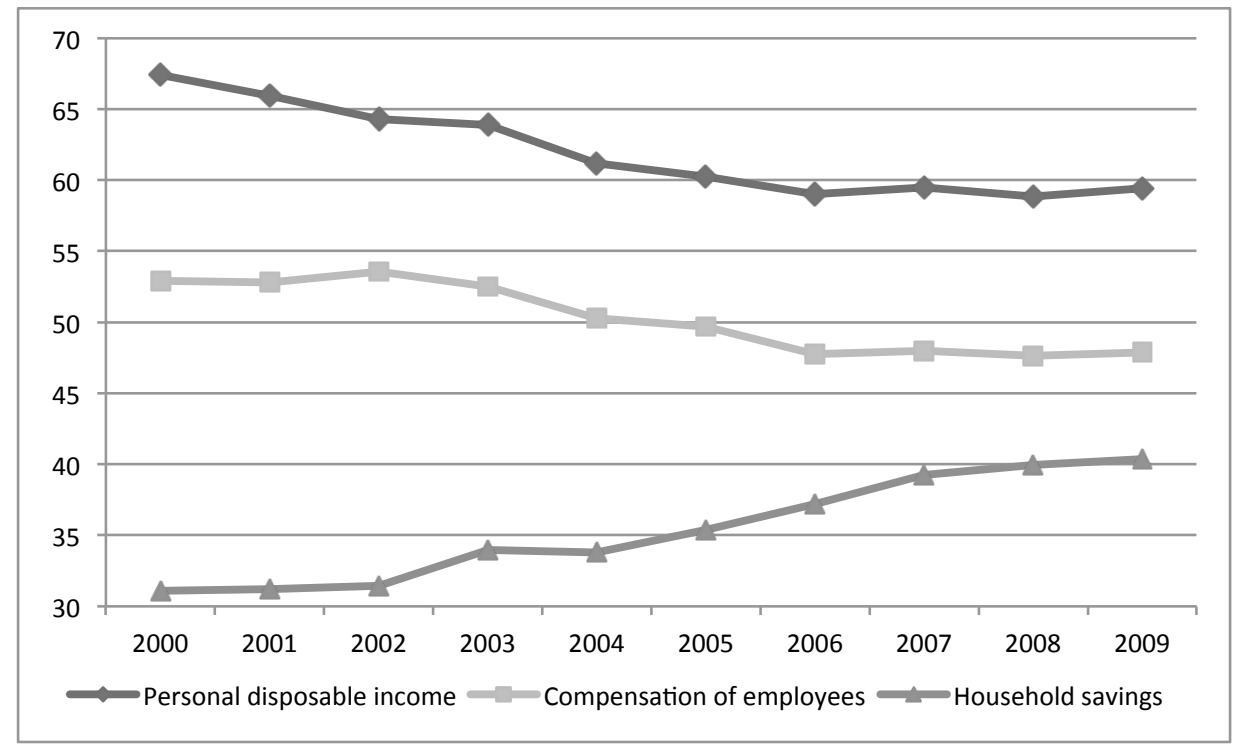

Source: National Bureau of Statistics; authors' calculations

Figure 4: Savings rate by sector, in per cent of GDP, 2000-2009

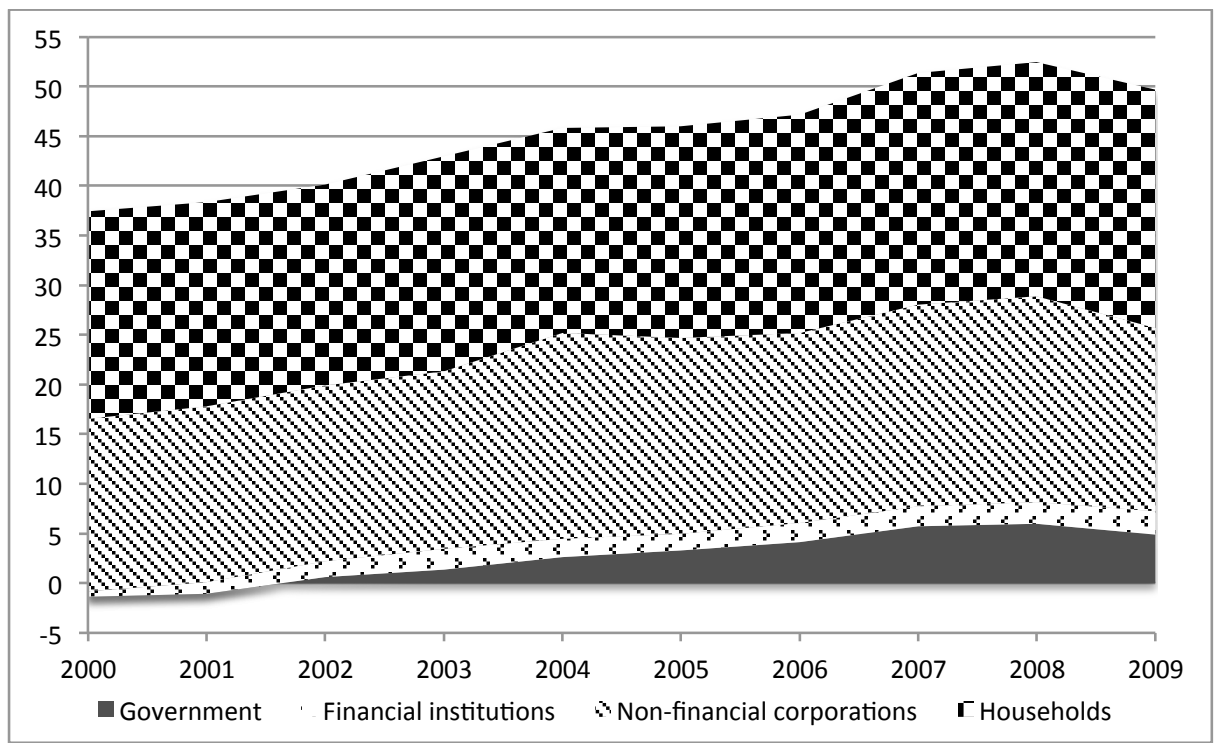

Source: National Bureau of Statistics, authors' calculations 
Figure 5: Financial balances by sector, in per cent of GDP, 2000-2009

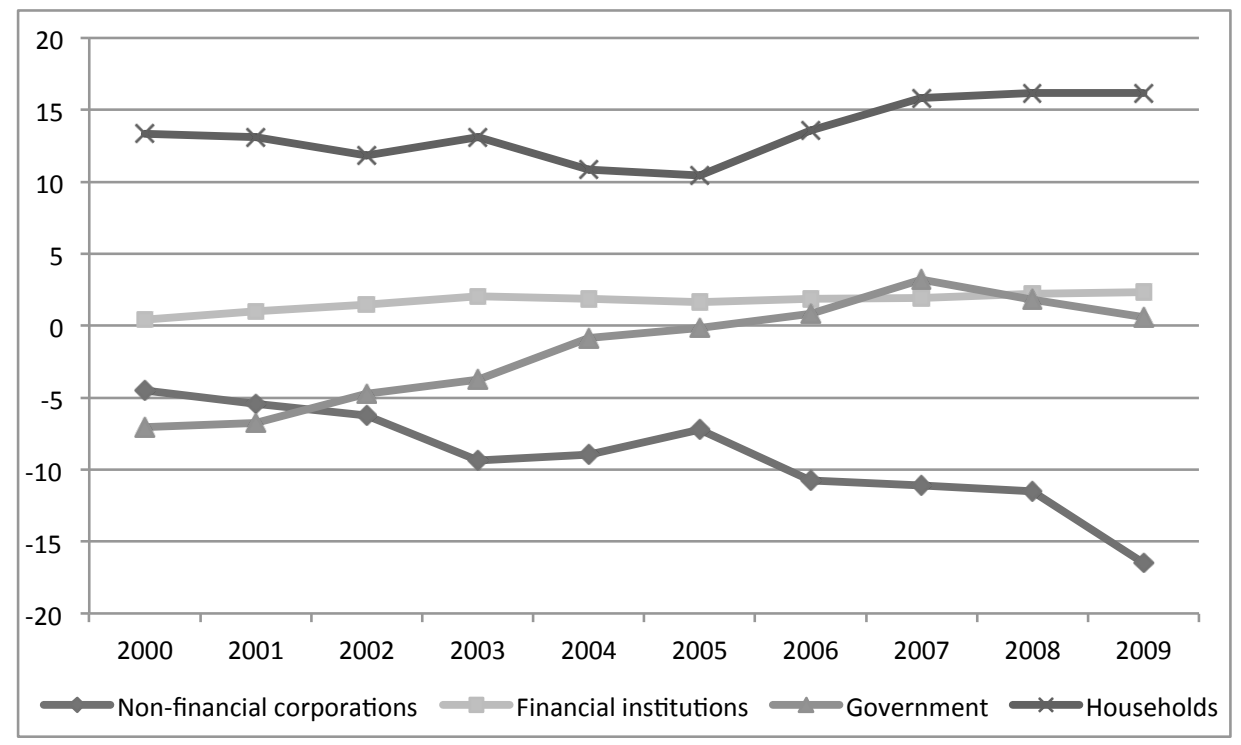

Source: National Bureau of Statistics

Figure 6: Wage share, in per cent of GDP, 1978-2007

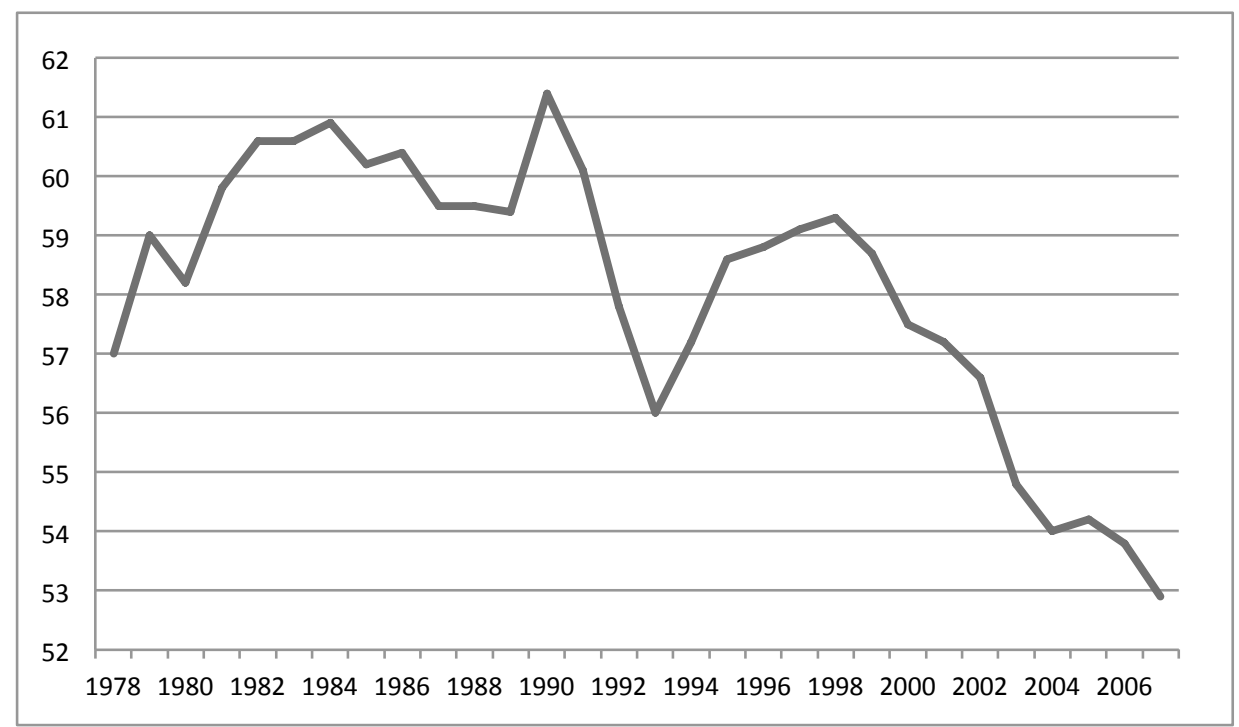

Source: Zhou, Xiao, and Yao, 2010, adjusted for statistical break 2004 
Figure 7: Gini coefficient, real yearly disposable income, 1985-2007

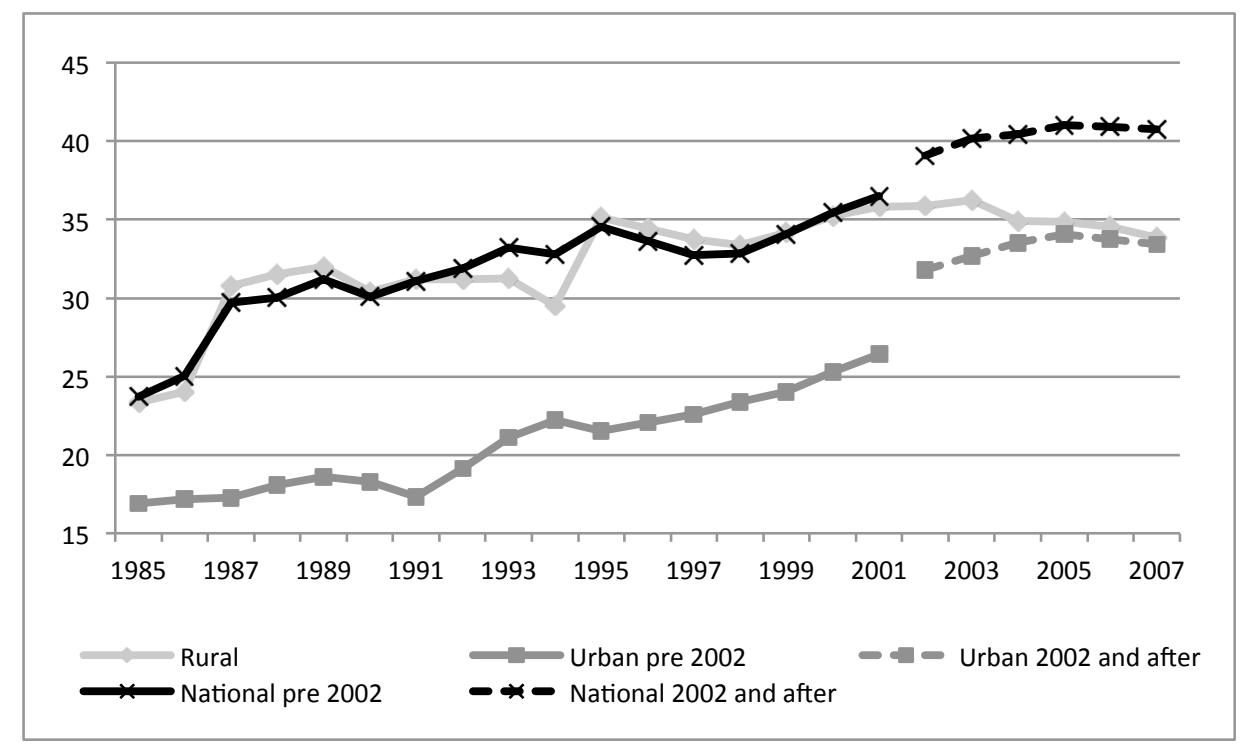

Source: NBS, OECD estimates, cited in $\operatorname{OECD}(2010$, p. 139, figure 5.6)

Figure 8: Top income shares, 1986-2003

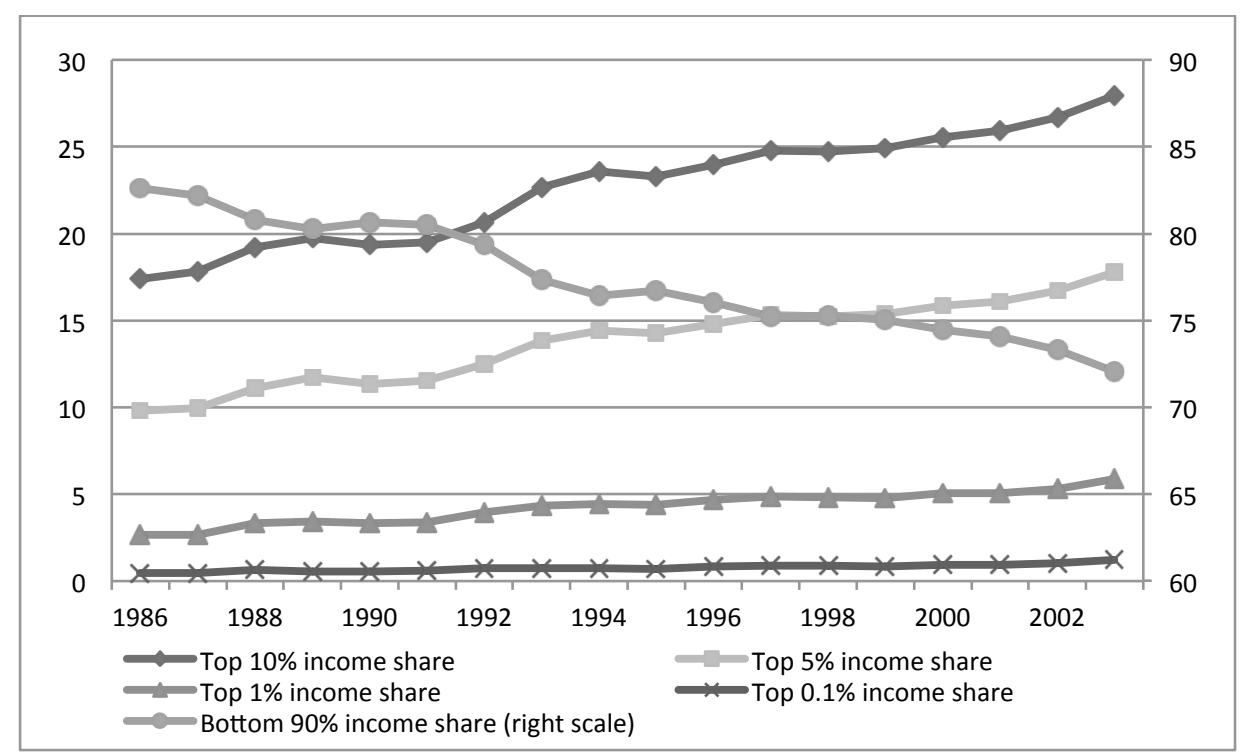

Source: Piketty and Qian (2009), based on China's National Statistical Bureau (NSB) urban household income surveys, data downloaded from The World Top Incomes Database 
Figure 9: Savings rates by age of household head, urban households

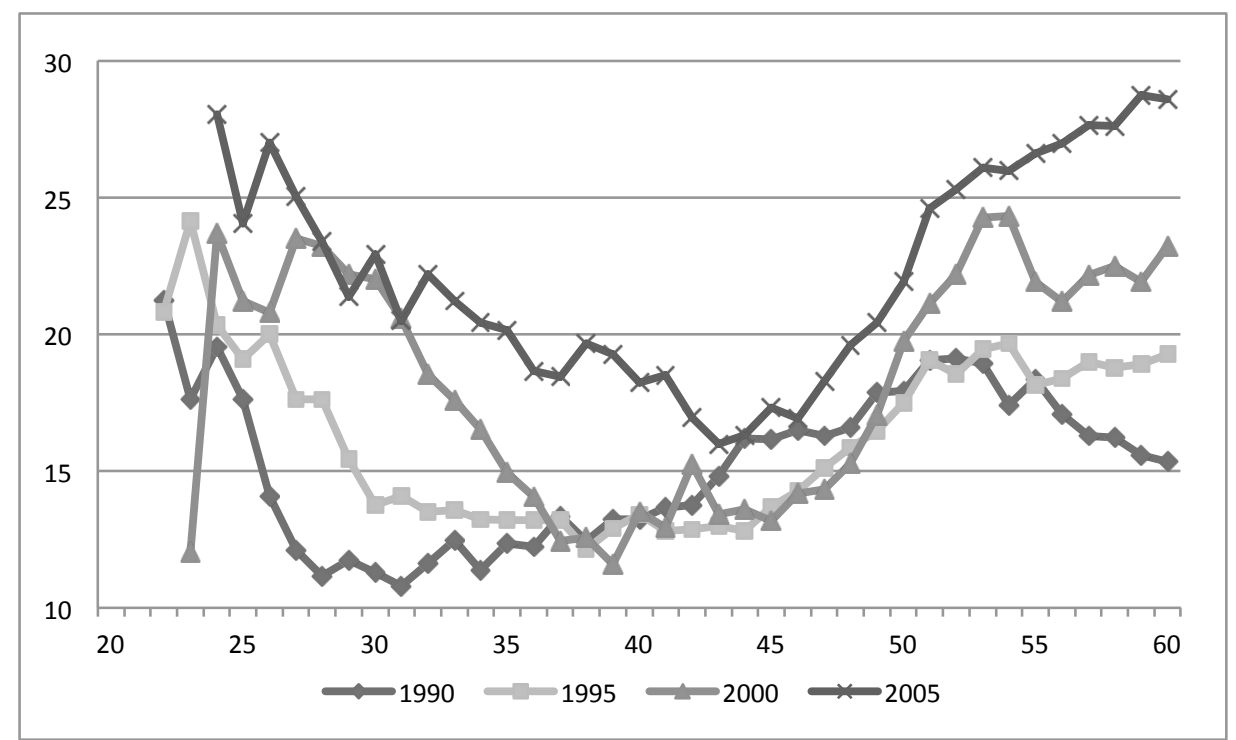

Source: Chamon, Cui and Prasad (2010, p. 32, figure 3), based on a 10 province/municipality subsample of the Urban Household Survey, National Bureau of Statistics

Figure 10: Savings rates by income deciles, urban households

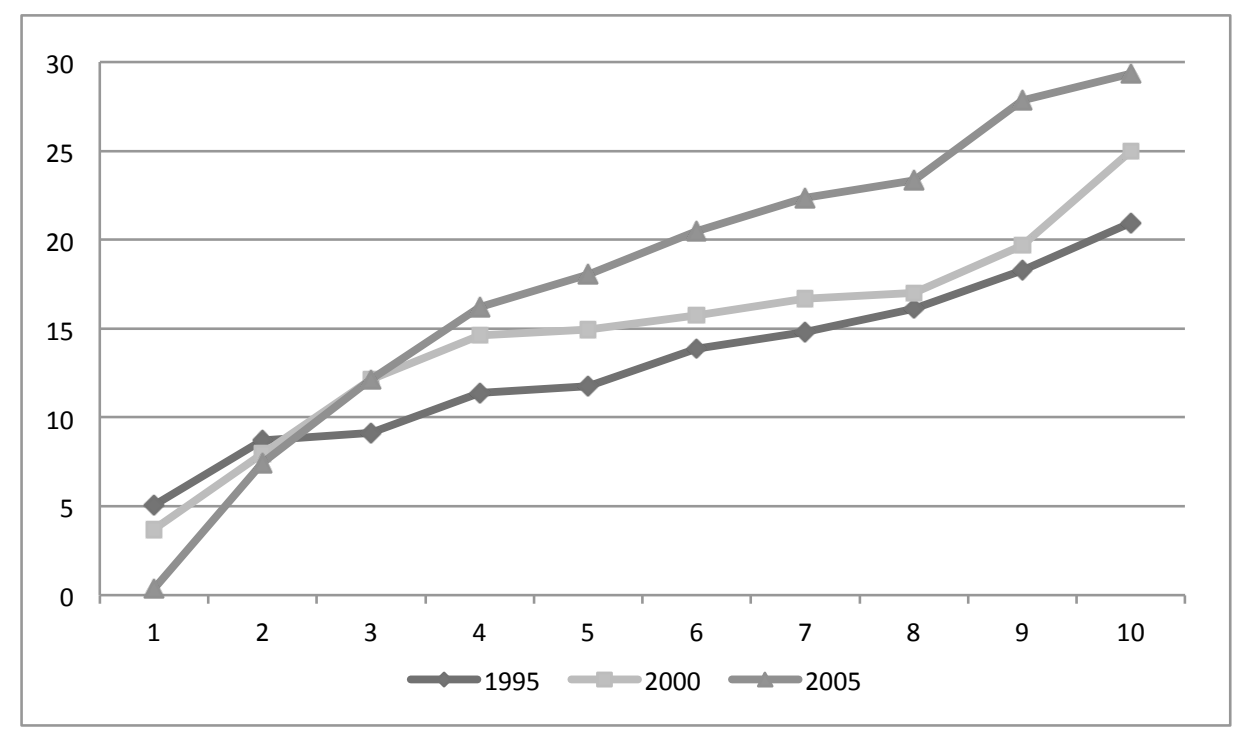

Note: Self-employed households excluded

Source: Chamon and Prasad (2010, figure 2, p. 99), based on Urban Household Survey 